\title{
Acculturation and Cultural Preferences of Second-Generation Iranians in Australia
}

\author{
Mona Asghari-Fard ${ }^{1}$ \\ ${ }^{1}$ University of Sydney, Australia \\ Correspondence: Mona Asghari-Fard, Liverpool Hospital, Mental Health Unit, L1 Elizabeth St, Liverpool NSW \\ 2170, Australia.
}

Received: December 8, 2017

Accepted: February 19, 2018

Online Published: March 1, 2018

doi:10.20849/aes.v3i1.321

URL: https://doi.org/10.20849/aes.v3i1.321

The author received no financial support for the research and/or authorship of this article (ORCID: 0000-0002-0069-3586).

\begin{abstract}
Migration has always played an essential role in the history of mankind. At present the intensity of cross- border mobility are much higher than in previous decades. In many countries, children of immigrants constitute a large sector of the population. These children live between two cultures and value systems: those of the parents' country of origin and of those of the host country. Living between two cultures requires cultural adjustment-referred to as acculturation.

Based on carefully targeted survey research, this quantitative study examines acculturation of second-generation Iranians (SGI) in Australia. It examines the interplay between participants' socio-demographic background, cultural practice, parental versus participants' cultural preferences, attitudes towards the host nation and cultural acquisition.

The results show patterns of biculturalism: while acculturated to the host culture, SGI prefer to maintain aspects of their native culture and tradition.
\end{abstract}

Keywords: second-generation Iranians, acculturation, cultural preferences, Iranians in Australia

\section{Introduction}

Migration has always played a vital role in the history of mankind, and while it has occurred for different reasons throughout history, it has invariably been in search of a better life. With migration comes adjustment to the new environment, culture and way of life. In recent years due to improved technology, and humanitarian and migration policies, the rate of cross-border mobility has been much higher than in previous decades. In fact, children of immigrants constitute a large sector of the population in many countries.

These children of immigrants, especially second-generation immigrants, live between two ways of life. At home they are raised in accordance with the value system of their parents' country of origin. In wider society they are educated, interact and live according to the host society's value system. Outside of the home, these children must navigate through a new culture, new people and often, a new language. In order to attain better integration, cultural adjustment to the host society is inevitable for immigrants and their offspring. When immigrants adopt parts or all of the host nation's way of life such as culture, language, etc., acculturation has occurred.

Migration and its aftermath-adjustment/acculturation-have been studied extensively (Berry, 1980, 2005; Julian, 1969; Jupp, 1998; Mahdi, 1998; Phinney, Horenczyk, Liebkind, \& Vedder, 2001; Rivett, 1962; Rumbaut \& Portes, 2001; Sabagh, 1994). The term acculturation is used to explore immigrants' level of adjustment to host culture. Acculturation scales measure type and degree of acculturation from native to host culture. This study evaluated the level of cultural change, or retention of native culture in second-generation Iranians (SGI) living in Australia against: demographic background, participants' cultural preferences, their parents' cultural preferences (for their children) and perception towards the host nation Australia. 


\section{Theoretical Framework: Models of Acculturation}

According to Berry (1989) the first major anthropological studies into acculturation took place in the 1930s. Two classic definitions(Redfield, Linton, \& Herskovits, 1936; Social Science Research Council, 1954) discussed by Berry, both suggest that acculturation resulted through some kind of continuous first-hand contact of different cultures. The Social Science Research Council identified acculturation as 'culture change that is initiated by the conjunction of two or more autonomous cultural systems' (1954:974) while Redfield, Linton and Herskovits suggest that acculturation is an aspect of cultural change.

Initially, acculturation was viewed as a one-dimensional process in which immigrants and their families were assumed to have abandoned their native culture, beliefs and way of life and replaced them with that of the host country (Redfield et al., 1936), in other words assimilated into the host culture. However, with increasing migration rates, globalisation (Phinney et al., 2001; Rumbaut \& Portes, 2001) and improved migration policies (Australian-Government, 2005; Collins, 1988, 2003; Hage, 1998; Jupp, 1998) this perception has changed. In the last few decades acculturation has become more of a bi-dimensional process, where immigrants retain part of their native culture and adopt aspects of the host society's culture. (Cabassa, 2003). Bi-dimensional theory of acculturation has been examined extensively. (Berry, 1980, 1994, 2003; Berry et al., 1989; Rogler, Cortes, \& Malgady, 1991; Szapoxznik, 1980). Berry's (1980) conceptualisation process of acculturation within a dimensional framework is one of the most comprehensive and widely used models of acculturation and has been used as a theoretical framework for this study.

Berry's acculturation theory (Berry, 1980, 2008) offers four possible outcomes: separation where individuals maintain their own culture; integration, where individuals follow patterns from both cultures; assimilation, where the new (host) culture is embraced; and finally, marginalisation where individuals do not follow either culture different contextual factors contribute to the type and degree of acculturation. Studies (Berry, 2006; Kim, Laroche, \& Tomiuk, 2001) show the process and degree of acculturation being largely a product of the interplay between individual characteristics of ethno-specific groups and the host nation's resources and settlement policies.

When it comes to children of immigrants, literature shows the components which form their acculturation expand to: the influence of their immediate social network and that of their parents (Dublin, 1996; Hong \& Hong, 1996), parental acculturation (Portes, 1996; Portes \& Stepick, 1993; Waters, 1996), that of their friends within the larger society, and that of the school environment and social network (Berry, 2006; Portes \& Rumbaut, 2006; Sabatier, 2008; Waters, 1996).

This study has made an attempt to examine acculturation and cultural preferences of SGI in Australia against the main contextual factors mentioned above. To this purpose, the socio-historical background of Australia and Iran is briefly discussed.

\subsection{Australia and Migration}

The history of Australia as a Western country began in 1700 with the colonisation of Australia by the British (Jupp, 1998). The first cultural interaction or clash experienced by the white settlers was with Australia's indigenous people, the Aborigines. From the time they arrived in Australia, the new settlers attempted to 'civilise' the Aboriginal people by making them wear clothes, attend church and assimilate into white society. The most undesirable aspect of this early assimilation policy was the forced removal of Aboriginal children, who were then placed in foster homes to be raised by white people and taught their way of life. The aim in removing the children from their communities was to break social relations with their Aboriginal elders and annul the child's individual ethno-cultural identity and his/her identity with an Aboriginal collective (Link-Up \& Wilson, 1997). These children became known as the Stolen Generation, and were the first children to become victims of cultural contact and power struggles in Australia.

Immigration history in Australia shows official government policies having been the main determining factor in the composition of Australian society (Adibi, 1994; Collins, 1988; Jupp, 1998). One of the first acts passed in the newly formed Federation of Australia in 1901 was, throughout the 19th century, a precursor to the 'White Australia Policy' and restricted 'non-white' immigration. The policy centred on white British or Irish immigration. The quest for ethnic purity established by these acts was in fact a quest for ethnic dominance within the nation (Hage, 1998). The 'White Australia Policy' continued for decades until it was abolished by the Whitlam Government in 1973 (Australian-Government, 2005).

Iranian immigration has occurred mainly since 1979 following the introduction of the multicultural policy in Australia and the era of tension between the West and East/Islam. 


\subsection{Iranians in Australia}

The Iranian communities in Australia and other countries had their beginnings after the fall of the Pahlavi government in 1979. Most of the Iranian migrants who settled around the world after 1979 are refugees who sought to escape Iran's Shia Muslim theocratic system established in 1979 (Adibi, 1994; Mahdi, 1998; Torbat, 2002; Vahdat, 1998). The process of adaptation to a new sociocultural context acculturation-has forced Iranians to confront many cultural barriers. A number of studies on Iranian acculturation have shown that first-generation Iranians acculturate selectively-taking the path of assimilation into the host culture through attainment of education and upward mobility, while concurrently maintaining their core homeland cultural beliefs, including family values (Chaichian, 1997; Hoffman, 1990; Mostofi, 2003). This in turn has influenced the acculturation of their children. As little is known about acculturation of second-generation Iranians in Australia, this study aimed to reduce this gap in knowledge.

\section{Methodology}

Participants: Children of Iranian immigrants who live in Australia: either born in Australia or who came to Australia before or aged 13, born to Iranian parents and aged 18 and over.

The criteria for "born to Iranian parents" allowed the researcher to measure the adaptation process, based on "pure" Iranian and "Australian" cultural attachment. Having one parent from a different nationality (either the host nation or other nationality) automatically influences not only the participants' sense of ethnic, national and cultural belonging, but also their upbringing.

Data Collection: A mail out and online survey were used to collect the data. The study was widely advertised (Iranian newspapers, radios, holy places, youth discos and places of entertainment) in states and cities where Iranians were known to live.

Site Selection: Site selection for this study was based on the Australian Bureau of Statistics (2006) data Iranian residents in Australia.

Measurements: Various strategies were used to develop instruments for this study to ensure the appropriateness of the instrument for the study population, these include: 1. Literature review based on extensive literature reviews on Iranian migration and acculturation (Adibi, 2003; Askari, 2003; M. Bozorgmehr, 1997, 1998; M. Bozorgmehr, \& Sabagh, G., 1991; Daniel \& Mahdi, 2006; Jalali, 1996), migration and acculturation patterns of other ethnic group and acculturation theories (Berry, 2008; Berry et al., 1989; Berry, Phinney, Sam, \& Vedder, 2006, 2010; Boyd, 2002; Cabassa, 2003; Chun, Balls Organista, \& Marín, 2003; Cleveland \& Laroche, 2007; Cuellar, Harris, \& Jasso, 1980; Dublin, 1996; Knight, Kagan, Nelson, \& Gumbiner, 1978; Kohbod, 1996). 2. Examining Iranian websites and youth chat rooms: observing and listening to parents and children about their life and adjustment in Australia. 3. Researchers' observation and experience with immigrants. 4. Consultation with four Iranian intellectuals in the field of psychology, sociology and population health about the questionnaire. 5. A draft of the questions was piloted. Our pilot study included five individual parents (to ensure parents did not find questions threatening to their safety) and SGI (to ensure they understood the questions and were happy to answer them). Measurements in this study were divided into four sections: demographic background, acculturation, cultural preferences of participants and their parents, and attitudes towards the host.

\subsection{Demographic Background}

Demographic background included 20 questions on participants' gender, age, religion, country of birth, age on arrival, education levels, including those of their parents, and reasons for migration, etc.

\subsection{Measuring Acculturation}

Acculturation is a complex construct that presents a challenge to investigators because it encompasses socio-economic, historical, political and psychodynamic variables. In this context measurements used to assess acculturation included immigrants' background, their socializing patterns and language usage (Hoffmann T, Dana RH, \& B., 1985; Klonoff EA \& H., 2000; Zhou, 1997b), parental influence (Adibi, 2003; Dublin, 1996; Hong \& Hong, 1996; Mahdi, 1998; Zhou, 1997a) and the host nation's attitude (Snowden LR \& AM., 1999). Level of acculturation for this study was examined through participants' cultural attachment.

Cultural Attachment: Cultural attachment was examined in two sections of cultural practice: a) language usage and b) socializing, food consumption and utilisation of Iranian services.

\subsubsection{Cultural Practice: Language Usage}

Language usage was examined in two sections: In the first section, language proficiency was measured by the participants' ability to read and write in Farsi (the only native language used in Iran's school system) versus 
English, and language preference was determined by the language participants identified as their main language. The second section focused on language spoken (with parents, friends and siblings) and media language. When it comes to language spoken, an important factor included were those Iranians whose mother tongue was not Farsi, but Kurdish, Azeri, Assyrian, Armenian and Balochi-the choice given here was 'parents' native'. Language spoken was measured by three questions that assessed speaking with: parents (SP), siblings (SS), and friends $(\mathrm{SF})$. The three language spoken items were added $(\mathrm{SP}+\mathrm{SS}+\mathrm{SP})$ to yield a cultural practice: Language Spoken Scale (LSS).

Usage of media is dependent on an individual's language proficiency and cultural attachment. People usually choose media according to their ability to understand and follow the message. In this study, four different types of media were chosen: radio, TV, music and newspaper-to assess participants' use of native/host language and cultural attachment. The four media language items were added to construct Cultural Practice: Language Usage Media (LUM).

For both language scales, a 5-point Likert scale was used, whereby $1=$ 'only parents' native language' to $5=$ 'only English', where the lower score meant greater native language usage. These two scales (LUM and LSS) were added to yield a Language Usage Scale (LUS), and ranged from 7-35 whereby $\alpha=0.882$.

\subsubsection{Cultural Practice: Socializing, Food Consumption and Service Usage}

This study also examined SGI socialization behaviour and the extent to which they consume native food and utilise Iranian services (Iranian general practitioner, dentist, shops ...). Three questions on socializing were included: socializing with Iranians, other ethnic groups and with Anglo-Australians). Questions in this section were also based on a 5-point Likert scale, whereby $1=$ 'always' to $5=$ 'never', where a lower score meant greater Iranian cultural practice.

Cultural practice socializing with Australians (reversed) and Iranians, consumption of native food, and Iranian services were added to construct Cultural Practice Scale: Socializing, Service Usage and Food Scale (SSFS). Socializing with other ethnic groups was retained in the SSFS, as its factor load strength was .40. However, given this too was a question with important face validity, it was measured separately.

Cultural Attachment Scale (CAS) was constructed by adding LUS and SSFS. There were 12 items in the scale, which ranged from 12-60, with 12 indicating attachment to the native culture and 60 being assimilation to host culture.

\subsection{Cultural Preferences}

Literature shows (Adibi, 2003; Hong \& Hong, 1996; Mahdi, 1998; Zhou, 1997b) that sometimes children of immigrants behave and live their lives in response to either their parents' expectation or their own acculturation. Iranians are family-orientated: family plays an important role in an individual's life, and men usually look after the women and children (Adibi, 1994). It is therefore expected that family, especially fathers, play an important role in children's cultural attachment. The role of family in the cultural behaviour and preferences of participants in this study was measured using the following six questions:

My parents prefer/I prefer to: 1) speak my native language; 2) follow Iranian tradition; 3) attend holy places; 4) attend Iranian gatherings); 5) marry someone with same religion; 6) marry someone from same ethnic background. Each item was based on a 5 -point Likert scale whereby $1=$ 'high preference' to $5=$ 'no preference towards native culture'.

An 'I Prefer Scale' (IPS) was constructed by adding all six questions, ranging between 5-30, with a Cronbach's Alpha of 0.821. A 'My Parents Prefer Scale' (PPS) was constructed similarly by adding six questions in this section, ranging between 5-30, with a Cronbach's Alpha of 0.881.

\subsection{Attitudes Towards the Host Country}

Host nation is another contextual factor that is known to play an important role in adaptation strategies employed by immigrants (Berry, 1997; Berry et al., 2006; Bourhis, Moise, Perreault, \& Senecal, 1997). Regardless of which side institutes the segregationist approach, studies (Dion, Dion, \& Pak, 1992; Fozdar, Wilding, \& Hawkins, 2009; Liebkind, Jasinskaja-Lahti, \& Teräsaho, 2007; Liu, 2007) have shown an association between prejudicial attitudes and acculturation outcomes. They also show that host community members' orientation towards a particular immigrant group may change from integrationist to exclusionist as more of the same group arrive in the host nation. Differences between majority and minority attitudes towards acculturation strategies can lead to in-group bias and perceived discrimination (Zagefka \& Brown, 2002), and segregation can be witnessed in passive form. A study in Sydney (Pe-Pua, Mickovska-Damcevska, \& Echevarria, 1996) 
investigated street activities of 100 people from Non English Speaking Backgrounds (NESB) in Sydney metropolitan suburbs, showed an association between racial identity and unfair treatment by police officers. As one of the participants, stated:

Cops pick on us and always seem to find something to charge us for (e.g. loitering) just because we're Lebanese...they just kick you out of train station. They never ask nicely. (p. 92).

Political parties in the host nation and the media can play an important role in creating negative attitudes towards an ethnic group (Bourhis et al., 1997). For example, Pauline Hanson, leader of One Nation Party, warned in one of her speeches that Australia was in danger of being swamped by 'Asians' (Hanson, 2010) and 'Muslims' (Merhab, 2016).

Another example in Australia is the Cronulla, Sydney riots, in 2005, which made headlines around the world when a group of 'Australian' youths targeted other 'Australian' youths of 'Middle-Eastern appearance'. According to a Herald reporter (2005), many Middle-Eastern-looking people were injured, while buses, trains and other public and private properties were damaged. During the riots not only second-and third-generation Australians with a Middle-Eastern background were targeted, many with the same racial appearance were attacked too. This sort of group victimisation has been witnessed in other countries (Mobasher, 2006). The media has on many occasions been criticised as a major culprit in promoting negative attitudes, such as refugees being undeserving and dangerous (Jakubowicz et al., 1994). In this study, these factors were examined using 11 questions. The answers to each question were recorded on a 5-point Likert scale.

The factor structure of this section was determined using a Principal Components Factor Analysis (see Table 1) with a varimax rotation. There were no outliers, and evaluation of assumptions-including the Kaiser-Meyer-Olkin measure of sampling adequacy and Bartlett's test of sphericity, were satisfactory. The best structure interpretation was a three-factor specified solution with a varimax rotation. Items were retained within a factor where a minimum factor load strength of .50 was achieved.

Table 1. Principle component factor analysis for attitudes towards host subscales

\begin{tabular}{|c|c|c|c|c|}
\hline Items and Scales & F1 & F2 & F3 & $\dot{\boldsymbol{\alpha}}$ \\
\hline Attitudes Towards Host & & & & .821 \\
\hline $\begin{array}{l}\text { In general, I feel this society does not like Middle } \\
\text { Eastern People }\end{array}$ & .829 & & & \\
\hline $\begin{array}{l}\text { In general, I feel this society does not like } \\
\text { Muslims }\end{array}$ & .813 & & & \\
\hline $\begin{array}{l}\text { I believe, discrimination is very much alive in } \\
\text { Australia }\end{array}$ & .772 & & & \\
\hline $\begin{array}{l}\text { I have been discriminated because of my } \\
\text { ethnicity }\end{array}$ & .757 & & & \\
\hline Trusts towards Australian Departments & & & & .761 \\
\hline I trust Australian government & & .906 & & \\
\hline I trust Australian government departments & & .865 & & \\
\hline I trust Australian political parties & & .812 & & \\
\hline I trust Australian media & & .435 & & \\
\hline I trust Australian police & & .414 & & \\
\hline Positive Attitudes Reversed & & & & .571 \\
\hline I like Australian society as a whole & & & .876 & \\
\hline I can integrate easily in Australian society & & & .814 & \\
\hline Total Attitudes 12 items & & & & .809 \\
\hline
\end{tabular}

\section{Factor 1: Discriminatory perceptive scale (DPS)}

Four negative statements were used: 1) I feel this society does not like Middle-Eastern people; 2) I feel this society does not like Muslims; 3) I believe discrimination is alive; 4) I have been discriminated against because of my ethnicity. With each item ranging from $1-5$, whereby $1=$ 'strongly disagree' and $5=$ 'strongly agree', the lower score indicated positive attitudes towards the host nation, and the higher score indicated negative attitudes with a range of 4-20 whereby $\alpha=0.821$. 


\section{Factor 2: Trust towards government authority (TGA)}

This scale had four items querying how much trust participants had in: 1) Australian government; 2) government departments; 3) political parties; 4) media and police, and ranged from 4-20 whereby $\alpha=0.761$.

Factor 3: Integrative perceptive scale (IPS)

Participants were also asked about their general feelings towards Australia and their integration experiences. This scale included two statements: 1) 'I like Australian society as a whole' and 2) 'I can integrate easily into Australian society' and ranged from 2-10 whereby $\alpha=0.571$. The Total Attitudes Scale (TAS) was constructed from the above three scales, 12 items (two IPS items were reversed before being added to the scale), with a range of $12-60$ whereby $\alpha=0.809$.

\section{Data Analysis and Findings}

SPSS software was used to analyse the current data.

\subsection{Demographic Background}

In total, 137 second-generation Iranians living in Australia aged 18-36 participated in this study. Participants were categorised in three age groups: young group (18-20 years old (31.4\%)); young adults $(21-25$ years old $(43.8 \%))$; and mature adults (26-36 years old (24.8\%)). Participants' age of arrival was also divided into three age groups: 0-4 years old (35\%); 5-8 years old (29\%); and 9-13 years old (36\%). A great majority (70.8\%) were born in Iran and half were Muslims (44.9\%); no religion (26\%); and (28\%) others. At the time of the survey a large number of participants (85.4\%) were single, and of this group, a great majority (84.2\%) were living with their parents.

A great majority $(65.7 \%)$ had also either finished a degree at university or were working towards one, and $(81.8 \%)$ were employed-full time, part time or causal. Most of the participants $(68.3 \%)$ lived in NSW, half the participants $(50.4 \%)$ came to Australia directly and (27\%) came through transition countries, with the remaining (22.6\%) born in Australia. The reasons for migration were divided into two categories: 'Oppression' and 'Others'. The former was included choices such as lack of freedom, ethnic, religious or political oppression, of which $69.3 \%$ chose one or more categories; the latter was included choices such as: war, better lives for themselves, better lives for their children, of which $27.8 \%$ chose one or more categories.

A great majority of the participants came from educated families, $45.3 \%$ of participants' mothers and $66.5 \%$ of participants' fathers had university degrees, including PhD, Master's and medical degrees.

\subsection{Participants' Level of Acculturation/Cultural Attachment}

As mentioned earlier in acculturation scales: the lower the score, the greater the attachment to native culture.

\subsubsection{Cultural Practice: Language Usage}

Language Proficiency: The results showed that all participants could speak Farsi/native, while more than half (53.5\%) could read and write Farsi. As expected, all participants could speak, read and write English. Bivariate analysis showing ability to read and write native language is associated with age of arrival, with those who arrived in Australia at an older age (9-13) being able to read and write Farsi compared with their younger counterparts, whereby $\mathrm{X}^{2}(2, \mathrm{~N}=102)=18.79, \mathrm{P} \leq 0.001 ; \mathrm{X}^{2}(2, \mathrm{~N}=102)=23.27, \mathrm{P} \leq 0.001$, respectively. Similarly, those who were born in Iran compared with those who were born in Australia, whereby $X^{2}(1, N=137)$ $=21.51 ; \mathrm{P} \leq 0.001 ; \mathrm{X}^{2}(1, \mathrm{~N}=137)=17.63 ; \mathrm{P} \leq 0.001$, respectively.

A great majority $(71.5 \%)$ chose English as their main language. Bivariate analysis shows that those who arrived in Australia at an older age were more likely than their younger counterparts to identify Farsi as their main language, whereby $\left.\mathrm{X}^{2}(4, \mathrm{~N}=99)=13.3 ; \mathrm{P} \leq 0.010\right)$. Furthermore, those who chose Farsi as their main language were able to read and write Farsi, whereby $\mathrm{X}^{2}(2, \mathrm{~N}=132)=8.917 ; \mathrm{P} \leq 0.030 ; \mathrm{X}^{2}(2, \mathrm{~N}=132)=12.91 ; \mathrm{P} \leq$ 0.044 , respectively.

Language Spoken: participants spoke a greater amount of native language with their parents $(57.7 \%)$ but more English with their siblings (58.4\% and friends (78.1\%). The mean for all items in media language usage was 4 or above, indicating that language usage for media was mainly the host language (English). Similar results were obtained with the Language Usage Scale.

\subsubsection{Cultural Practice Scale: Socializing, Food and Services (CPSSFS)}

Socializing: When it comes to socializing, more than half (53.2\%) always/most of the time socialized with other ethnic groups, $27.2 \%$ of participants always/most of the time socialized with Iranians and only $29.4 \%$ socialized always/most of the time with Anglo-Australians. A great majority (89\%) always/most of the time ate Iranian 
food, while only a small percentage utilised Iranian shops (6.6\%) and the services of Iranian professionals (11\%). An independent t-test showed that language usage and SSFS are associated with the education of participants' fathers, whereby $\mathrm{t}(124)=-3.119 ; \mathrm{p} \leq 0.003, \mathrm{t}(124)=-2.46 ; \mathrm{P} \leq 0.017$; Mean father no university education $=$ 15.2; Mean father university education $=16.89$, respectively. Participants whose fathers were non-university educated tended to use less English language to communicate with their parents, and their cultural practice tended to be closer to their native culture.

The analysis of variance (ANOVA) shows that there is a significant association between LU, main language and age of arrival are statistically significant at $\mathrm{F}(2,129)=16.395, \mathrm{P} \leq 0.001 ; \mathrm{F}(2,99)=4.018, \mathrm{P} \leq 0.003$, respectively. Those who identify English as their main language, those who arrived before the age of nine tended to use more English language. Furthermore, ANOVA results show that associations between SSFS, main language and religion $\mathrm{F}(2,127)=6, \mathrm{P} \leq 0.003 ; \mathrm{F}(2,131)=7.4, \mathrm{P} \leq 0.001$, respectively. Those who chose English as their main language scored a higher mean (lean towards host culture) than those who chose both languages (Farsi/native and English) as their main language (see table 2). Ironically, those who chose both languages tended to be closer to native culture (lowest mean score: $M=14$ ), that is, their cultural practice tended to lean more towards the native culture than those who chose Farsi as their main language. For the Cultural Attachment Scale 12 items indicated overall patterns of integration with mean and standard deviation of $(\mathrm{M}=44.4 ; \mathrm{SD}=3.5)$.

Total cultural attachment was classified as follows:

- separation: low score in cultural attachment (12-18.99)

- integration: moderate score between two cultures

- bi-native: acculturated more to native culture (19-35.99)

- bi-host: acculturated more to host culture (36-47.99)

- assimilation: high score in cultural attachment (48-60)

Table 2. ANOVA and compare means of cultural attachment sub-scales and scales

\begin{tabular}{|c|c|c|c|}
\hline Variables & $\begin{array}{l}\text { Language Usage Scale (LUS) } \\
\text { Mean(SD) }\end{array}$ & $\begin{array}{l}\text { Socializing, } \\
\text { Services (SSFS) } \\
\text { Mean(SD) }\end{array}$ & $\begin{array}{l}\text { CAS } \\
\text { Mean(SD) }\end{array}$ \\
\hline Main language & $F(2,127)=26.4, p \leq .001$ & $F(2,127)=6, p \leq .003$ & $F(2,125)=19.7, p \leq .001$ \\
\hline Farsi & $24.3(3.95)$ & $15.5(3.8)$ & $39.9(6.5)$ \\
\hline Both & $23.4(5.6)$ & $14(3)$ & $37.5(8.1)$ \\
\hline English & $29.3(3.4)$ & $17(3)$ & $46.4(5.7)$ \\
\hline Age of arrival & $F(2,98)=6.36, p \leq .003$ & $F(2,98)=.0691, p \leq 503$ & $F(2,98)=3.547, p \leq .033$ \\
\hline $0-4$ & $28.6(3.5)$ & $16.3(3.7)$ & $44.9(6)$ \\
\hline $5-8$ & $29(3.2)$ & $17.1(2.8)$ & $46.1(5.1)$ \\
\hline $9-13$ & $25.7(5.3)$ & $16.2(3.6)$ & $41.9(8.1)$ \\
\hline Religion & $F(2,131)=3.4, p \leq .035$ & $F(2,132)=7.4, p \leq .001$ & $F(2,129)=6.291, p \leq .002$ \\
\hline No Religion & $29.08(4.4)$ & $17.6(3.7)$ & $46.7(7.3)$ \\
\hline Muslim & $26.81(4.3)$ & $15.3(3.2)$ & $42.1(6.3)$ \\
\hline Others & $28.5(4.7)$ & $17.4(3.1)$ & $45.9(7.2)$ \\
\hline
\end{tabular}

\subsection{Cultural Preferences}

With regard to Cultural Preferences items, results show that parental and participants' preferences are almost aligned, parents having a slightly higher preference for children to speak their native language and follow their traditions, than is the preference of the children themselves.

Independent $t$ tests show that the fathers' education is the only background information having significant association with parental preferences, whereby $\mathrm{t}(126)=3.301$; $\mathrm{P} \leq 0.002$. Those whose fathers were not university educated (FNU) tended to have a preference for their children to follow their culture of origin $\left(\mathrm{M}_{\mathrm{Fnu}}=\right.$ 14.76), while those whose fathers were university educated (FU) showed less preference for their children to follow their ancestral culture, with a mean score of $\left(\mathrm{M}_{\mathrm{FU}}=18.79\right)$. When it came to religious background and cultural practice, parents of non-Muslim participants tended to have a higher preference for their children to follow their culture $(M=15.82)$, than those whose were Muslim $(M=17.35)$ or were of no religion $(M=20.95)$ - the higher mean indicating less preference for practising culture of origin. 
Furthermore, the ANOVA results show that the IPS is significantly associated with main language and religion, whereby $\mathrm{F}(2,128)=9.6 ; \mathrm{P} \leq 0.001 ; \mathrm{F}(2,132)=8.232 ; \mathrm{P} \leq 0.001$, respectively. Those who chose Farsi/native (FN) as their main language tended to have a higher preference towards native culture than those who chose both languages (B), including those who nominated English (E) as their main language. This is evidenced by the means $\left(\mathrm{M}_{\mathrm{FN}}=15.1, \mathrm{M}_{\mathrm{B}}=16.1\right.$ and $\left.\mathrm{M}_{\mathrm{E}}=20.6\right)$ respectively.

\subsection{Attitudes Towards the Host Country}

Factor 1: Discriminatory Perceptive Scale (DPS)

This scale shows that $62 \%$ believed discrimination to be alive in Australia and the same percentage said that this country does not like Muslims. The DPS ranged from 4-20 (M=13.5; $\mathrm{SD}=3.6)$.

Factor 2: Trust towards Government Authority (TGA)

Of the four questions, the highest level of distrust exhibited was towards the Australian media: $43.8 \%$ stated that they did not trust the Australian media. The TGA scale was M=13.7 and SD = 3.9.

Factor 3: Integrative Perceptive Scale (IPS)

A great majority (86.9\%) liked Australian society as a whole and $88.3 \%$ said they could integrate easily into society. The range for this scale was $2-10,(\mathrm{M}=3.7 ; \mathrm{SD}=1.3)$. The Total Attitude Scale ranged from 11-55, (M $=27 ; \mathrm{SD}=6.24)$ with a lower scale score indicating positive perception. An independent t-test showed association between all three attitude subscales (DPS; ATGOS; IPS) and state of residency $(t=2.024 ; \mathrm{p} \leq 0.046)$; those who did not reside in NSW had a less discriminatory perception towards the host.

DPS is marginally associated with age of arrival $F(2,101)=3.11, \mathrm{p} \leq .049$. Those who arrived between the ages of 5-8 had less discriminatory perception than their counterparts. Those who chose English as their main language tended to have a more positive integrative experience than their counterparts, $\mathrm{F}(2,132)=4.448, \mathrm{p} . \leq .014$.

\subsection{Acculturation and Contextual Factors}

Linear regression results show that:

Religion, main language and age of arrival can predict $27 \%\left(\mathrm{AR}^{2}=0.270\right)$ of participants' cultural attachment. Those who chose Farsi as their main language are closer to the native culture than the other two groups $(\mathrm{B}=$ $-4.443 ; \beta=-0203 ; \mathrm{t}=-2.554 ; \mathrm{p} \leq .012)$. Also, those whose fathers were not university educated tended to be closer to the native culture $(\beta=.024 ; \mathrm{t}=3.023 ; \mathrm{p} \mathrm{p} \leq .003)$. Cultural preferences predict $40 \%$ of participants' CAS $\left(\mathrm{R}=.642 ; \mathrm{AR}^{2}=0.403\right)$. The PPS is not significantly associated with participant CAS usage $(\mathrm{P} \leq 0.565)$.

Using linear regression association between attitude sub-scales and cultural attachment scales show that $9 \%$ $\left(\mathrm{AR}^{2}=0.094\right)$ of participants' cultural practice is predicted by their total attitude toward the host (three scales), in particular their trust of the host governments' organisations and media $(t=-2.866 ; p \leq 0.005)$. Those who had less trust toward government departments tended to be more involved in their native culture and community; perception of discrimination and attitude towards the host are not associated with SSFS $(p \leq 0.166 p \leq 0.267)$, respectively. Attitudes toward the host predict $4 \%$ of the language usage of participants $\left(\mathrm{AR}^{2}=.038\right)$.

Those who use more host language tend to integrate and like Australian society more $(B=-.0830 ; t=-2.839 ; \mathrm{p} \leq$ 0.005). Perception of discrimination and trust in the government has no significant association with the language usage of participants. Participants' attitudes towards the host nation and government predicted $4 \%$ of their cultural attachment $\left(\mathrm{AR}^{2}=0.39\right)$. Those participants who had a better attitude and perception of the host nation (Australia) tended to be more host-orientated culturally, whereby $\left(\beta=-.177 ; \mathrm{B}=-.200 ; \mathrm{R}=.177 ; \mathrm{R}^{2}=.031 ; \mathrm{AR}^{2}\right.$ $=.024 ; \mathrm{F}=4.061 ; \mathrm{p} \leq .046$ ). This is shown in Table 3 . 
Table 3. Linear regression analysis of TCAS and demographic

\begin{tabular}{|c|c|c|c|c|c|}
\hline & & $\mathbf{B}$ & Beta & $\mathbf{t}$ & Sig \\
\hline \multirow[t]{6}{*}{ A CAS } & (Constant) & 40.308 & & 17.608 & 0.000 \\
\hline & Muslims vs Others & -2.903 & -0.201 & -2.164 & 0.032 \\
\hline & No Religion vs other religion & 0.316 & 0.020 & 0.214 & 0.831 \\
\hline & $\begin{array}{l}\text { Father Education: } \\
\text { None university vs university } \\
\text { education }\end{array}$ & 3.800 & 0.240 & 3.023 & 0.003 \\
\hline & Farsi vs English & -4.443 & -0.203 & -2.554 & 0.012 \\
\hline & Both vs English & -7.027 & -0.330 & -4.108 & 0.000 \\
\hline \multicolumn{6}{|c|}{$(\mathrm{R}=0.547 ; \mathrm{R} 2=0.299 ; \mathrm{AR2}=0.270 ; \mathrm{F}=10.083 \mathrm{P} \leq 0.001)$} \\
\hline \multirow[t]{3}{*}{ CAS } & (Constant) & 30.424 & & 19.309 & .001 \\
\hline & PPS & -.062 & -.059 & -.577 & .565 \\
\hline & IPS & .789 & .685 & 6.676 & .001 \\
\hline
\end{tabular}

\section{Discussion}

This study examined acculturation preferences of second-generation Iranians in Australia, utilising a bi-dimensional understanding of acculturation, believing the bi-dimensional model to be better suited to the second generation of today.

In a bi-cultural context, immigrants and their offspring have the opportunity and choice to adopt aspects of either host or native culture. Decades ago the children of immigrants were encouraged and/or pushed to assimilate into the mainstream culture and in the process sacrificed their parents' cultural heritage. At the same time, parents and ethnic communities pushed their children to maintain their native culture. In the contemporary context the second generation have the option of picking and choosing aspects of either culture.

Participants of this study brought up in Australia's multicultural society were not under pressure to melt into the host culture or abandon their native culture. At the same time, findings show that when it comes to family expectations, participants' parents are not forceful in making them socialize within the Iranian community, and are not particularly concerned about their children's or their children's partner's religious beliefs or ethnicity. The participants of this study did not therefore experience the push and pull of those forces.

In this study, we aimed to contribute to a better understanding of the acculturation of SGI in Australia by examining the cultural preferences of participants and those of their parents. Also taken in account were the effects of other variables on participants' preferences or those of their parents, such as age of arrival, reasons for migration, parents' education and employment.

This study then measured participants' acculturation level. As mentioned earlier, the measurement of acculturation used was instigated by Berry's acculturation model. Considering Berry's model, our results mainly showed patterns of integration to both cultures, with no assimilation, separation or marginalisation witnessed. This is in line with other studies on children of Iranians outside the homeland (Adibi, 2003; Darya, 2007; Mahdi, 1998).

In addition, findings show SGI in Australia consciously prefers to retain aspects of their native culture, and chose aspects of the host culture. This is an important factor in understanding the second generation's willingness to accept the values of the host country and treat it as their home. Thus, this study further dissected Berry's integration category into 'bi-native' and 'bi-host' in order to reflect participants' preference of the level of integration into both cultures.

By bi-native we mean that although the second generation has integrated with the host culture through language proficiency, socializing or other factors influencing their acculturation, they still retain more Iranian culture than their counterpart bi-host group. Those in the bi-native category were more competent in their native language, called Farsi/native their main language rather than English; preferred to marry within the same ethnic group and socialized more within their native community, but were not separated from the host culture.

On the other hand, those who were categorised as bi-host showed that although they had less desire to retain Iranian culture, they were not assimilated. Our results showed that the decision to retain particular aspects of their host or native cultures in either group were made consciously and therefore need to be reflected in their 
acculturation category. Putting both groups under the umbrella of integration-bicultural did not explicate their conscious decision to retain or discard specific aspects of either culture.

Generally the findings show that the degree of integration-biculturalism varied in different cultural aspects within both groups. For example, the majority were not particular about having a partner from the same ethnic or religious group and did not utilise Iranian services. However, when it came to language, one of the most important components of cultural acquisition was that almost all participants used a great deal of Farsi/native in communicating within their family-especially with their parents, but also within the community.

Retainment of native language in the second generation was found in other studies (Adibi, 2003; Cheng \& \& Kuo, 2000; Darya, 2007; Haeri Darya, 2006; Sabagh, 1994; Zevallos, 2004). It does, however, need to be kept in mind that retaining native language could be more of out of necessity than choice. Mismatched host language proficiency amongst parents and children has been recognised as the main reason for children speaking their native language with parents, (Hong \& Hong, 1996; White \& Wyne, 2008) hence the need to retain native language. Though parents' English proficiency was not examined in this study, the findings show that those participants whose parents were university educated tended to use more English to communicate with their parents. This could be interpreted as the parents' proficiency in the host language having enabled children to express themselves in English when they found it difficult to communicate in their mother tongue.

The findings also show that in both groups, language was the main variable affecting their acculturation. Those who were not proficient in their native language tend to be distanced from their native community. On the other hand, those who recognised Farsi/native as their main language and could communicate better in Farsi/native tend to socialise more within their native society. The reverse of this situation was found in the first generation, who socialized within their own community rather than with the host community, due to a limited ability to converse in the host language. For this reason, host countries have for many years been encouraging immigrants and their children to communicate in the host language whilst enforcing monolingualism, in order to integrate immigrants and their children into the host society.

With respect to media, the majority of participants mainly/only listen to English music; however as Cohen (2006) highlights, Western media is popular even among Iranian youth both in or out of Iran, as in Kohbod's (1996) study in which most of the Iranian immigrants from different backgrounds aged 30-39 enjoyed American media. This could also be due to the fact that the implicit limitations of the post-revolutionary regime in Iran prevented the development or cultivation of a modern Iranian culture (Mahdi, 1998; Torbat, 2002). Thus there is 'no' or limited living, developing culture able to meet this generation's media (music, video and youth magazines) needs.

When it comes to host input, SGI like other second generations in Australia have faced discrimination (Butcher \& Thomas, 2003; Ghosh, 2003; Zevallos, 2004). Despite the fact that many participants of this study have been discriminated against or believe discrimination to be alive in Australia, their overall attitudes towards the host nation are positive and they claim to be capable of integration into society.

This is in line with other studies on Iranian acculturation where Iranians residing in other countries were also found to be capable of integration into the host society (Adibi, 2003; Haeri Darya, 2006; Mahdi, 1998).

\section{Conclusion}

Due to the small sample size, no meaningful generalisations can be made regarding second-generation Iranians' acculturation in Australia based on this study. The main conclusion to be drawn from this study is this: despite differences in their socio-demographic background, most SGI or their parents came to Australia to escape the oppressive regime and the insecurity in Iran; they appreciate the positive aspects of their adopted country, such as freedom and better opportunities in life; the majority have taken the path of bi-culturalism and don't feel pushed by their parents to follow their tradition. Their cultural preferences are not far removed from those of their parents. It could also be said that Iranian parents are becoming more culturally relaxed, and/or well acculturated themselves.

\section{Strength and Limitations}

This is the first quantitative study in Australia on second-generation Iranians. Although the results of this study are informative, the limitations of this research are also noted.

This study was limited in regard to the small sample size. The response rate in other Iranians studies has also been low (Mostofi, 2003). The main contributing factors of this limitation were: 
- An inherent distrust among Iranians made many reluctant to disclose personal opinions-this perhaps as a result of the political situation in Iran. The requirement for both parents being Iranian also limited the number of participants.

- The age of arrival was a restriction that prevented some people from participating in the study. Many second-generation Iranians were very young when they left Iran, having lived in transitional countries for years before arriving in Australia after the age of 13.

\section{Future Research}

Further research is needed to examine acculturation of second-generation Iranians in Australia, using a large sample and incorporating measures used in other countries, such as those in Europe and America, in order to make international comparisons possible.

\section{Acknowledgments}

The authors would like to express their gratitude to the second-generation Iranians who participated in this study, to Dr. Syeda Zakia Hossain who supervised this study. Dr. Gomathi Sitharthan who co-supervised this study and has recently passed away, and to the Iranian intellectuals who commented on early drafts of questionnaire.

\section{References}

Adibi, H. (1994). Iranians in Australia. Mehregan in Sydney. Sydney: Persian Cultural Foundation of Australia.

Adibi, H. (2003). Identity and social change: the case of Iranian Youth in Australia. Paper presented at the Social Change in the 21st Century. Queensland: Queensland University of Technology.

Askari, G. (2003). A cultural relativistic approach toward Iranian immigrants in therapy. The Sciences and Engineering, 64(6-B), 2940-2921.

Australian-Government. (2005). Fact sheet-Abolition of the 'White Australia' Policy. Retrieved from https://www.border.gov.au/about/corporate/information/fact-sheets/08abolition\#b

Berry, J.W. (1980). Acculturation as varieties of adaptation. Acculturation: Theory, Models and Some New Findings, 9-25.

Berry, J.W. (1994). Acculturation and psychological adaptation: An overview.

Berry, J.W. (1997). Immigration, acculturation, and adaptation. Applied Psychology, 46(1), 5-34. https://doi.org/10.1111/j.1464-0597.1997.tb01087.x

Berry, J.W. (2003). Conceptual approaches to acculturation. In M. Chun, O. P. \& G. Marín (Eds.), Acculturation: Advances in theory, measurement, and applied research (1st ed., pp. 17-37). Washington, DC American Psychological Association. https://doi.org/10.1037/10472-004

Berry, J.W. (2005). Acculturation: Living successfully in two cultures. International Journal of Intercultural Relations, 29(6), 697-712. https://doi.org/10.1016/j.ijintrel.2005.07.013

Berry, J.W. (2006). 3 Contexts of acculturation. In J. W. Berry (Ed.), The Cambridge Handbook of Acculturation Psychology (pp. 27-42). Cambridge: Cambridge University Press. https://doi.org/10.1017/CBO9780511489891.006

Berry, J.W. (2008). Globalisation and acculturation. International Journal of Intercultural Relations, 32(4), 328-336. https://doi.org/10.1016/j.ijintrel.2008.04.001

Berry, J.W., Kim, U., Power, S., Young, M., \& Bujaki, M. (1989). Acculturation attitudes in plural societies. Applied Psychology, 38(2), 185-206. https://doi.org/10.1111/j.1464-0597.1989.tb01208.x

Berry, J.W., Phinney, J.S., Sam, D.L., \& Vedder, P. (2006). Immigrant youth: Acculturation, identity, and adaptation. Applied psychology, 55(3), 303-332. https://doi.org/10.1111/j.1464-0597.2006.00256.x

Berry, J.W., Phinney, J.S., Sam, D.L., \& Vedder, P. (2010). Immigrant youth. Acculturation, identity and adaptation (pp. 1-17). Germany: Beltz Verlag.

Bourhis, R.Y., Moise, L.C., Perreault, S., \& Senecal, S. (1997). Towards an interactive acculturation model: A social psychological approach. International Journal of Psychology, 32(6), 369-386. https://doi.org/10.1080/002075997400629

Boyd, M. (2002). Educational attainments of immigrant offspring: Success or segmented assimilation?. International Migration Review, 36(4), 1037-1060. https://doi.org/10.1111/j.1747-7379.2002.tb00117.x 
Bozorgmehr, M. (1997). Internal Ethnicity: Iranians in Los Angeles. Sociological Perspectives, 387-408. https://doi.org/10.2307/1389449

Bozorgmehr, M. (1998). From Iranian studies to studies of Iranians in the United States. Iranian Studies, 31(1), 4-30. https://doi.org/10.1080/00210869808701893

Bozorgmehr, M., \& Sabagh, G. (1991). Iranian exiles and immigrants in Los Angeles In A. F. C. Mesa (Ed.), Iranian exiles and refugees since Khomeini (pp. 121-144). California: Mazda publishers.

Butcher, M., \& Thomas, M. (2003). Being in-between a. Melbourne: Pluto Press.

Cabassa, L.J. (2003). Measuring acculturation: Where we are and where we need to go. Hispanic Journal of Behavioral Sciences, 25(2), 127-146. https://doi.org/10.1177/0739986303025002001

Chaichian, M.A. (1997). First generation Iranian immigrants and the question of cultural identity: The case of Iowa. International Migration Review, 612-627. https://doi.org/10.2307/2547288

Cheng, S., \& \& Kuo, W. (2000). Family socialization of ethnic identity among Chines American prre-aolescents. Journal of Coparative Family Studies, 31, 463-482.

Chun, K.M., Balls Organista, P.E., \& Marín, G.E. (2003). Acculturation: Advances in theory, measurement, and applied research. American Psychological Association. https://doi.org/10.1037/10472-000

Cleveland, M., \& Laroche, M. (2007). Acculturaton to the global consumer culture: Scale development and research paradigm. Journal of Business Research, 60(3), 249-259. https://doi.org/10.1016/j.jbusres.2006.11.006

Cohen, J. (2006). Iran's young opposition: youth in post-revolutionary Iran. SAIS Review, 26(2), 3-16. https://doi.org/10.1353/sais.2006.0031

Collins, J. (1988). Migrant hands in a distant land: Australia's post-war immigration. Pluto Press Sydney.

Collins, J. (2003). Cultural diversity and entrepreneurship: policy responses to immigrant entrepreneurs in

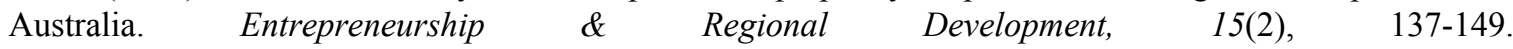
https://doi.org/10.1080/0898562032000075168

Cuellar, I., Harris, L.C., \& Jasso, R. (1980). An acculturation scale for Mexican American normal and clinical populations. Hispanic Journal of Behavioral Sciences, 2, 199-217.

Daniel, L., \& Mahdi, A.A. (2006). Culture and customs of Iran. USA: Greenwood Publishing Group.

Darya, F.H. (2007). Second-generation Iranian-Americans: The Relationship Between Ethnic Identity, Acculturation, and Psychological Well-being. Retrieved 2008, from http://search.proquest.com/docview/304722563

Dion, K.L., Dion, K.K., \& Pak, A.W. (1992). Personality-based hardiness as a buffer for discrimination-related stress in members of Toronto's Chinese community. Canadian Journal of Behavioural Science/Revue Canadienne Des Sciences Du Comportement, 24(4), 517. https://doi.org/10.1037/h0078755

Dublin, T. (1996). Becoming American, Becoming Ethnic: College Students Explore Their Roots. Philadelphia: Temple University Press.

Fozdar, F., Wilding, R., \& Hawkins, M. (2009). Race and ethnic relations. South Melbourne Victoria: Oxford University Press.

Ghosh, D. (2003). I can make chutney out of anything: Young Indians growing up in Sydney. In B. M. \& M. Thomas (Eds.), Ingenious Emerging Youth Culutres in Urban Australia (pp. 66-84). Melbourne: Pluto Press.

Haeri Darya, F. (2006). Second generation Iranian-Americans: The relationship between ethnic identity, acculturation, and psychological well-being. Capella University Ann Arbor, USA. Retrieved from http://gateway.proquest.com/openurl?url_ver=Z39.88-2004\&res_dat=xri:pqdiss\&rft_val_fmt=info:ofi/fmt:k ev:mtx:dissertation\&rft_dat=xri:pqdiss:3242155

Hage, G. (1998). White nation: Fantasies of white supremacy in a multicultural society. Routledge.

Hanson, P. (2010). Pauline Hanson's Maiden Speech in Federal Parliament 1996.

Herald-reporter. (2005). Mob violence envelops Cronulla. The Sydney Morning Herald. Retrieved from www.smh.com.au/news/national/mob-violence-envelopscronulla/2005/12/11 
Hoffman, D.M. (1990). Beyond conflict: Culture, self, and intercultural learning among Iranians in the US. $\begin{array}{llll}\text { International Journal of Intercultural Relations, } & \text { 14(3), 275-299. }\end{array}$ https://doi.org/10.1016/0147-1767(90)90016-P

Hoffmann, T, Dana, R.H., \& Bolton, B. (1985). Measured acculturation and MMPI-168 performance of Native American adults. Journal of Cross-cultural Psychology, 16(2), 243-256. https://doi.org/10.1177/0022002185016002007

Hong, J., \& Hong, S. (1996). The Korean American Family: Assimilation and Its Toll on the First and Second Generation Relationship. Retrieved 1997, from http://eric.ed.gov/?id=ED401348

Jakubowicz, A., Goodall, H., Martin, J., Mitchell, T., Randall, L., \& Seneviratne, K. (1994). Racism, ethnicity and The media. Sydney: Allen \& Unwin.

Jalali, B. (1996). Iranian families, J. G. K. P. M. McGoldrick (Ed.). New York: Guilford Press.

Julian, R. (1969). Multiculturalism. In J. Germov (Ed.), Second Opinion and Introduction to Health Sociology. Melbourne: Melbourne University Press.

Jupp, J. (1998). Immigration (2nd ed.). Melbourne: Oxford University Press.

Kim, C., Laroche, M., \& Tomiuk, M.A. (2001). A measure of acculturation for Italian Canadians: Scale development and construct validation. International Journal of Intercultural Relations, 25(6), 607-637. https://doi.org/10.1016/S0147-1767(01)00028-1

Klonoff E.A., \& H., L. (2000). Revising and improving the African American acculturation scale. Journal of Black Psychology, 26(2), 235-261. https://doi.org/10.1177/0095798400026002007

Knight, G.P., Kagan, S., Nelson, W., \& Gumbiner, J. (1978). Acculturation of Second-and Third-Generation Mexican American Children Field Independence, Locus of Control, Self-Esteem, and School Achievement. Journal of Cross-cultural Psychology, 9(1), 87-97. https://doi.org/10.1177/002202217891007

Kohbod, A. (1996). The Interrelationship of Acculturation, Social Support, Coping, Spiritual Well-being Proficiency, and Locus of Control to Psychological and Iranian Depressive Symptoms among Iranian Immigrants. California.

Liebkind, K., Jasinskaja-Lahti, I., \& Teräsaho, M. (2007). Ingroup vitality and intergroup attitudes in a linguistic $\begin{array}{llll}\text { minority. Scandinavian Journal of Psychology, 48(5), } & \text { 409-418. }\end{array}$ https://doi.org/10.1111/j.1467-9450.2007.00591.x

Link-Up, \& Wilson, J. (1997). In the best interest of the child? Stolen children: Aboriginal pain/White shame. NSW: National Libary of Australia.

Liu, S. (2007). Living with others: Mapping the routes to acculturation in a multicultural society. International Journal of Intercultural Relations, 31(6), 761-778. https://doi.org/10.1016/j.ijintrel.2007.08.003

Mahdi, A.A. (1998). Ethnic identity among second-generation Iranians in the United States. Iranian Studies, 31(1), 77-95. https://doi.org/10.1080/00210869808701897

Merhab, B. (2016). Pauline Hanson: Australia 'in danger of being swamped by Muslims'. The Australian Newspaper of the Year, September 14. Retrieved from http://www.theaustralian.com.au/news/latest-news/all-eyes-on-hanson-for-first-senate-speech/news-story/08 6648acbbdb63bdac6e8ec5cf080778

Mobasher, M. (2006). Cultural trauma and ethnic identity formation among Iranian immigrants in the United States. American Behavioral Scientist, 50(1), 100-117. https://doi.org/10.1177/0002764206289656

Mostofi, N. (2003). WHO WE ARE: The Perplexityo f Iranian-AmericaInd entity. The Sociological Quarterly, 44(4), 681-687. https://doi.org/10.1111/j.1533-8525.2003.tb00531.x

Pe-Pua, R., Mickovska-Damcevska, N., \& Echevarria, A. (1996). We're just like other kids: street-frequenting youth of non-English-speaking background. Australian Government Pub. Service.

Phinney, J., Horenczyk, 1., Liebkind, K., \& Vedder, P. (2001). Ethnic identity, immigration, and well-being: An interactional perspective. Journal of Social Issues, 57(3), 493-510. https://doi.org/10.1111/0022-4537.00225

Portes, A. (1996). The new second generation. Russell Sage Foundation. 
Portes, A., \& Rumbaut, R.G. (2006). Immigrant America: a portrait. Oaklan, California: Univ of California Press.

Portes, A., \& Stepick, A. (1993). City on the edge: The transformation of Miami. Univ of California Press.

Redfield, R., Linton, R., \& Herskovits, M.J. (1936). Memorandum for the study of acculturation. American Anthropologist, 38(1), 149-152. https://doi.org/10.1525/aa.1936.38.1.02a00330

Rivett, K. (1962). Immigration: Control or colour Bar? The background to 'White Australia' and a proposal for change. Melbourne University Press, Melbourne.

Rogler, L.H., Cortes, D.E., \& Malgady, R.G. (1991). Acculturation and mental health status among Hispanics: Convergence and new directions for research. American Psychologist, 46(6), 585. https://doi.org/10.1037/0003-066X.46.6.585

Rumbaut, R.G., \& Portes, A. (2001). Ethnicities: Children of immigrants in America. Univ of California Press.

Sabagh, G., \& Bozorgmehr, M. (1994). (1994). Secular Immigrants: Ethnicity and religiosity among Iranian Muslims in Los Angeles. In Y. H. J. Smith (Ed.), Muslim Communities in North America (pp. 445-473): SUNY Press.

Sabatier, C. (2008). Ethnic and national identity among second-generation immigrant adolescents in France: The role of social context and family. Journal of Adolescence, 31(2), 185-205. https://doi.org/10.1016/j.adolescence.2007.08.001

Snowden L.R., \& AM., H. (1999). A scale to assess African American acculturation. Journal of Black Psychology, 25, 36-47. https://doi.org/10.1177/0095798499025001003

Social Science Research Council. (1954). Acculturation: An Exploratory Formulation. American Anthropologist, 56, 973-1002.

Statistics, A. B. O. (2006).

Szapoxznik, J., \& Kurtines, M. (1980). Acculturation, biculturalism, and adjustment among Cuban Americans In A.M.Padilla (Ed.), Psychological dimensions on he acculturation process: Theory, models, and some New Findings (pp. 139-159). Boulder: CO: Westview.

Torbat, A.E. (2002). The brain drain from Iran to the United States. The Middle East Journal, 272-295.

Vahdat, N. (1998). Iranians. In J. Jupp (Ed.), The Australian People: An Encyclopedia of the Nation, its People and Their Origins. Canberra: Cambridge University Press.

Waters, M. (1996). Immigrant families at risk: factors that undermine changes of success. In A. C. A. Booth, \& N. Landale (Ed.), Iimmigration and the Family: Research and Policy on U.S. Immigrants (pp. 7a9-78). New Jersey: Lawrence Elbaum.

White, R., \& Wyne, J. (2008). Youth \& society: Exploring the Social Dynamics of Youth Experience. Melbourne Oxford University Press.

Zagefka, H., \& Brown, R. (2002). The relationship between acculturation strategies, relative fit and intergroup relations: immigrant-majority relations in Germany. European Journal of Social Psychology, 32(2), 171-188. https://doi.org/10.1002/ejsp.73

Zevallos, Z. (2004). You have to be Anglo and not look like me': Identity and belonging among young women of Turkish and Latin American backgrounds in Melbourne, Australia. Australian Geographer, 39(1), 21-43. https://doi.org/10.1080/00049180701877410

Zhou, M. (1997a). Growing up American: The challenge confronting immigrant children and children of immigrants. Annual Review of Sociology, 63-95. https://doi.org/10.1146/annurev.soc.23.1.63

Zhou, M. (1997b). Segmented assimilation: Issues, controversies, and recent research on the new second generation. International Migration Review, 975-1008. https://doi.org/10.2307/2547421

\section{Copyrights}

Copyright for this article is retained by the author(s), with first publication rights granted to the journal.

This is an open-access article distributed under the terms and conditions of the Creative Commons Attribution license (http://creativecommons.org/licenses/by/4.0/). 